\title{
CRENÇAS, RELIGIÕES E ESTADO DE DIREITO
}

\section{BELIEFS, RELIGIONS AND THE RULE OF LAW}

\author{
Sebastião P. Mendes da Costa ${ }^{1}$ \\ Carlos Alberto Molinaro²
}

\begin{abstract}
RESUMO: Este trabalho é um estudo sobre a religiăo, o direito fundamental de liberdade religiosa e sua percepçâo como direito cultural. Através de uma pesquisa bibliográfica e jurisprudencial, numa perspectiva interdisciplinar, verificamos que no Estado Democrático de Direito a religiăo deve conviver com a igualdade, dignidade da pessoa humana, justiça social e pluralismo intercultural. E se a religiăo também é fruto da cultura, a sua proteçâo deve ser feita nos mesmos moldes da proteçâo aos direitos culturais.
\end{abstract}

PALAVRAS-CHAVE: Direitos culturais. Liberdade religiosa. Proteçāo jurídica.

\begin{abstract}
This work is a study on religion, the fundamental right of religious freedom and its perception as a cultural right. Through a bibliographical and jurisprudential research, in an interdisciplinary perspective, we verify that in the democratic state of right, religion must live with equality, dignity of the human person, social justice and intercultural pluralism. And if religion is also the fruit of culture, its protection must be made in the same way as the protection of cultural rights.
\end{abstract}

KEYWORDS: Cultural rights. Religious freedom. Legal protection.

1 Professor do curso de Direito da Universidade Federal do Piauí-UFPI, campus de Teresina-PI, Brasil. Pós-doutor em Direito Civil e Filosofia do Direito pela Universidade de Augsburg (Alemanha). Doutor em Direito pela PUCRS. Mestre em Direito, Estado e Constituiçăo pela UnB. Mestre em Antropologia e Arqueologia pela UFPI. Bacharel em Direito pela UnB. Advogado. prof.sebastiaocosta@gmail.com

2 Professor do Programa de Pós-Graduaçáo em Direito - Mestrado e Doutorado- PUCRS. Doutor em Direito pela Universidade Pablo de Olavide, Sevilha, com mençăo europeia. carlos.molinaro@pucrs.br 


\section{INTRODUÇÃO}

Esse trabalho é um estudo sobre a religiăo³, o direito fundamental de liberdade de crença religiosa e a sua percepçâo como direito cultural, como produto da cultura que exige uma proteçâo também pelos artigos 215 e 216 da Constituiçáo Federal Brasileira que busca salvaguardar a diversidade cultural. Prevista expressamente no texto constitucional, a proteçâo a liberdade religiosa é tema do direito constitucional no Estado Democrático de Direito uma vez que tenta harmonizar tal direito com a dignidade humana, a justiça social e o pluralismo intercultural. Se o Estado é democrático e de Direito, é dever proteger o pluralismo cultural. Como parte importante da cultura, as questóes religiosas devem ser protegidas para se evitar um fundamentalismo religioso que tente desconsiderar as minorias, dentro de uma lógica de proteçăo a liberdade de consciência e de busca pela tolerância.

Essa proteçâo é de suma importância, uma vez que a inviolabilidade às liberdades de consciência, de religiâo (crença ou culto) e de convicçáo político filosófica obriga o Estado a resguardar as suas manifestaçôes. Cumpre à lei, inclusive, proteger os locais onde as liturgias religiosas (com suas várias acepçóes de nomenclatura) se realizam.

Essa temática, porém, nâo pode ser tratada apenas com um enfoque jurídico e religioso. É necessário se estabelecer uma ampla abordagem interdisciplinar, utilizando-se de análises da Sociologia e da Antropologia Social para se compreender o fenômeno em seu aspecto global, visto que as crenças săo elementos da identidade cultural e servem para indicar o pertencimento de um indivíduo a um grupo social. Os modos de vida do ser humano incluem seu sistema de crenças, e dessa forma, protegido pela liberdade religiosa, mas gozam também de proteçâo enquanto direitos culturais. Neste trabalho, vamos referir sobre a religiâo e a proteçăo jurídica da liberdade religiosa no âmbito constitucional. Analisaremos a religiăo como produto da cultura e abordaremos a sua proteçăo enquanto elemento da diversidade cultural. Ainda sobre a metodologia empregada, os temas enfrentarâo uma abordagem interdisciplinar, com a abordagem de autores clássicos da Sociologia e da Antropologia Social, além de uma breve discussâo jurídica que considera aspectos jurisprudenciais. Mostraremos que a religiăo, enquanto processo cultural, deve ser protegida também como direito cultural.

\section{ESTADO LAICO E RELIGIÃO}

A separaçăo entre Estado e religiăo é uma das grandes conquistas da cultura ocidental. O fundamento do Estado no início era religioso. O chefe do poder político detinha também o poder religioso e era tratado como um Deus, tendo o poder natural de comandar. Com o renascimento na Europa e o Iluminismo, essas ideias começam a ser contestadas (FARIA, 2009) e geram a derrocada do absolutismo político. O marco jurídico dessa independência ao poder natural e fortalecimento do poder popular é a Constituiçấo dos Estados Unidos. Essas ideias também foram protegidas em seguida na França, com a Declaraçâo dos Direitos do Homem e do Cidadâo de 1789. É nesse momento que há um reconhecimento da liberdade religiosa. A separaçấo entre Estado

3 Parte da pesquisa bibliográfica deste trabalho foi realizada durante período de pesquisa de pósdoutorado na Universidade de Augsburg (Alemanha). 
e religiăo fortalece a liberdade de crença e de consciência infundindo a criaçăo dos direitos humanos no período moderno. Ao comentar sobre a separaçăo entre Estado e religiăo, Edilsom Faria (2009) afirma que essa separaçăo é uma grande conquista da cultura ocidental e que foi responsável por conquistas como o avanço e a liberdade da ciência, o respeito aos direitos fundamentais, a tolerância ao pluralismo religioso, assim como foi responsável pela democracia política.

O chamado Estado laico foi introduzido no Brasil com a proclamaçăo da República. Segundo Edilsom Faria (2009), temos como fatos imediatos a isso a mudança da administraçâo dos cemitérios, que passam a ser geridos pela Administraçăo Pública e o casamento, que passa a ser civil.

Atualmente o Brasil é um estado laico, conforme estabelece o art. 19, I, da Constituiçâo Federal de 1988:

“Art. 19. É vedada a Uniāo, aos Estados, ao Distrito Federal e aos Municípios:

Estabelecer cultos religiosos ou igrejas, subvencioná-los, embaraçar-lhes o funcionamento ou manter com eles ou seus representantes relaçóes de dependência ou aliança, ressalvada, na forma da lei, a colaboraçâo de interesses públicos; "

Mesmo com a presença da mençăo à proteçăo de Deus já no preâmbulo ${ }^{4}$ da Constituiçấo Federal, nâo podemos perder de vista que o Estado Brasileiro é laico e, portanto, faz diferenciaçấo entre as atividades do Estado e as questôes religiosas. Estado laico, porém, nâo significa uma aversâo à religiâo, uma hostilidade a ela ou mesmo um ateísmo, pois assim estaríamos privilegiando uma forma de pensar a respeito das questôes religiosas. De acordo com o preâmbulo da Constituiçăo Federal Brasileira de 1988:

"Nós, representantes do povo brasileiro, reunidos em Assembléia Nacional Constituinte para instituir um Estado Democrático, destinado a assegurar o exercício dos direitos sociais e individuais, a liberdade, a segurança, o bem-estar, o desenvolvimento, a igualdade e a justiça como valores de uma sociedade fraterna, pluralista e sem preconceitos, fundada na harmonia social e comprometida, na ordem interna e internacional, com a soluçáo pacífica das controvérsias, promulgando, sob a proteçăo de Deus, a seguinte Constituiçăo da República Federativa do Brasil. [grifo nosso]

O Estado laico está mais próximo do agnosticismo (LEITE, 2014, p. 326). Há um respeito em relaçăo a religiăo, devendo-se inclusive permitir aproximaçôes entre Estado e religiâo quando envolver o interesse público e desde que essas alianças sejam reguladas mediante lei.

É nesse contexto de Estado laico e cooperaçâo que se insere a proteçâo a liberdade religiosa que trataremos nesse trabalho.

$4 \quad$ Na ADI 2076-5/AC (DJ 08.08.2003), Rel. Ministro Carlos Velloso, asseverou:

"II - Preâmbulo da Constituiçáo: nâo constitui norma central. Invocaçáo da proteçăo de Deus: nâo se trata de norma de reproduçấo obrigatória na Constituiçăo estadual, nâo tendo força normativa". 


\section{EVOLUÇÃO DO DIREITO FUNDAMENTAL A LIBERDADE DE CRENÇA}

As liberdades de consciência, de crença e de culto sâo algumas das reivindicaçôes mais antigas dos cidadâos e alguns dos primeiros direitos a serem reconhecidos como direitos humanos e direitos fundamentais. Em tratados internacionais e mesmo na Constituiçăo Federal de 1988, essas liberdades sâo tratadas de forma diferenciada. Apesar dos diversos pontos em comum, tais direitos (liberdade de crença e liberdade de culto săo chamadas de liberdade religiosa) náo se confundem. Liberdade de consciência seria algo mais amplo, uma vez que as chamadas objeçôes de consciência envolvem hipóteses năo previstas na seara religiosa (SARLET, 2015).

Essas liberdades săo basilares para um Estado Democrático de Direito que busca regular uma sociedade plural, que evita os chamados fundamentalismos religiosos e busca a convivência de pessoas com respeito a dignidade humana e a justiça social.

O respeito a liberdade religiosa deve ser entendido como uma necessidade estatal de neutralidade que náo pode ser confundida com aversăo a questôes religiosas ${ }^{5}$ e muito menos com intolerância religiosa. Deve haver uma convivência harmoniosa entre as religiōes majoritárias com respeito às manifestaçōes religiosas minoritárias ${ }^{6}$, embora esse equilíbrio muitas vezes seja conflitante ${ }^{7}$.

Essas minorias religiosas săo tratadas por WEINGARTNER NETTO, que afirma:

Diante desse programa normativo, deve-se operar com um conceito amplo de liberdade religiosa e de religiáo (um âmbito normativo alargado), que aposte no maior grau de inclusividade (abertura para religióes minoritárias e inconvencionais) compatíveis com a igual liberdade e dignidade dos cidadâos, anteparos ao fundamentalismo-militante, que discrimina e que se impor aos năo crentes. (WEINGARTNER NETTO, 2013, p. 267)

O direito à liberdade de convicçâo religiosa abrange, inclusive, o direito de nâo acreditar em fé alguma, estando o Estado responsável pela defesa, também, do ateísmo .

$5 \quad$ O STF entendeu que em respeito à liberdade religiosa é dever da Justiça estimular a prática da religiăo pelo seu caráter pedagógico, que o beneficiário de suspensâo condicional da pena (sursis) náo pode ser proibido de frequentar, auxiliar ou desenvolver cultos religiosos em locais náo especificamente destinados ao culto. "A Justiça deve estimular no criminoso, notadamente primário e recuperável, a prática da religiâo, por causa do seu conteúdo pedagógico, nada importando o local". RE 92.916/81. Rel. Min. Antônio Neder. DJ 26.06.1981.

6 Após a Guerra dos Trinta Anos, os cidadāos dos muitos pequenos estados da Alemanha tiveram que viver de acordo com o princípio "cuius regio, eius religio", um princípio do Tratado da Paz Religiosa de Augsburg de 1555 entre a forças católicas e luteranas na Alemanha. Tal princípio foi reafirmado na Paz de Westphalia em 1648. Com isso, houve uma proteçấo das minorias religiosas que optaram por nâo alterar a sua confissâo, sendo concedido direito de emigraçáo (jus emigrandi). Cf. GORNIG, Gilbert; TRUE, Christiane. Minority Protections in Germany. 6 Tilburg Foreign Law Review 69, 1997. p. 79.

7 A Corte Europeia de Direitos Humanos decidiu em 01.07.2014 pela validade de lei francesa que proíbe cidadáos de cobrirem toda a face em público. A polêmica lei francesa teria provocado a saída de adolescentes mulçumanos das escolas após essa proibiçâo. (THE EUROPEAN COURT OF HUMAN RIGHTS, 2014)

8 Gerhard Robbers (2001), ao estudar a liberdade religiosa na Alemanha, defende que a liberdade religiosa é uma questăo fundamental em qualquer comunidade que seja comprometida com a idéia de direitos humanos. Na Constituiçăo Alemă, a liberdade religiosa significa liberdade de crença e liberdade de agir de acordo com as suas crenças, ou seja, uma idéia de liberdade positiva.

Na Alemanha, a liberdade religiosa também está presente na Constituiçáo dos Länders, na jurisprudência e em acordos entre o governo e organizaçōes religiosas específicas. O direito à religiáo é visto a partir de três princípios: liberdade, neutralidade e tratamento igualitário. A liberdade religiosa năo pode 
Năo podemos compreender, porém, a liberdade religiosa separada da identidade sociocultural, e é por isso que no Estado Democrático de Direito, o direito constitucional aborda tal matéria harmonizando liberdade religiosa com igualdade, dignidade da pessoa humana, justiça social e pluralismo intercultural.

\title{
2.1 LIBERDADE DE CONSCIÊNCIA E LIBERDADE DE RELIGIĂO (ART. 50, VI E VIII, DA CONSTITUIÇĀO FEDERAL DE 1988)
}

Liberdade de consciência e liberdade de religiăo sâo direitos fundamentais distintos. Enquanto a liberdade de consciência é entendida como uma faculdade do indivíduo de autodeterminar aspectos de ordem ética, garantidora de uma autonomia do próprio indivíduo, a liberdade de religiâo é vista como a liberdade de ter ou năo uma religiấo, e abrange a liberdade de crença, liberdade de expressâo em matéria religiosa, liberdade de culto, direito a assistência religiosa, além de direitos como de reuniăo e associaçâo e privacidade no aspecto religioso (WIENGARTNER NETO, 2013). Todos esses direitos estâo protegidos pela Constituiçấo Federal de 1988 , em especial no seu artigo $5^{\circ}$, incisos VI, VII e VIII. Segundo Fábio de Carvalho Leite:

\begin{abstract}
"A proteçấo constitucional à liberdade religiosa, portanto, năo se refere à tutela a uma corrente de ideias ou de pensamento, mas à compreensâo de um direito mais amplo de liberdade de consciência, que assegura a autodeterminaçăo existencial e ética dos indivíduos, a defesa do seu âmbitode racionalidade e de consciência, e que se desdobra em diversos campos, como o filosófico, o ideológico e o religioso." (LEITE, 2014, p. 308)
\end{abstract}

\subsection{LIBERDADE DE CRENÇA E DE CULTO}

A liberdade de crença é entendida como a faculdade do indivíduo escolher uma religiấo, assim como a liberdade de mudar de religiăo ou mesmo a possibilidade de náo seguir religiâo alguma. Por outro lado, a liberdade de culto está relacionada a manifestaçăo exterior da crença, ou seja, da manifestaçăo de atos que săo próprios a essa religiâo. Teríamos entâo a liberdade religiosa dividida em dois aspectos, um interno que seria a liberdade de crença, e outro externo, que seria a manifestaçáo do culto, que pode ser no templo, mas também em grupos ou mesmo individualmente. (NAME apud LEITE, 2014, p. 312). Dessa forma, a liberdade de culto poderia sofrer limitaçóes. Já a liberdade de crença năo teria essa possibilidade de limitaçâo. Como afirma Fabio Carvalho Leite:

“Desse modo, deve-se assumir que a liberdade de crença é o direito de exprimir uma crença e năo o de ter uma crença (condiçăo necessária, mas năo suficiente à caracterizaçấo deste direito fundamental). Reconhece-se que o conteúdo deste direito compreende contornos mais amplos do que o de simplesmente poder-se

simplesmente ser limitada por uma lei sob a justificativa de se reforçar o interesse público. É necessário se estabelecer um equilíbrio entre interesses públicos legítimos e a liberdade religiosa. Gerhard Robbers (2001, p. 648) mostra exemplos de decisóes de Cortes Alemâs, como é o caso de decisâo do Tribunal Administrativo Federal ("Das Bundesverwaltungsgericht"), em favor da liberdade religiosa e contrárias ao interesse público, como é o caso da decisâo que permitiu que alunos e professores possam participar de tradiçôes religiosas que possam interferir com os regulamentos de escolas públicas. 
afirmar possuir uma crença, mas é este o seu núcleo de proteçăo. É dizer: é claro que a plena realizaçáo do direito à liberdade de crença depende náo apenas do direito de exprimir a crença, mas de uma autodeterminaçăo existencial a partir dela." (LEITE, 2014, p. 313)

\subsection{ESCUSA DE CONSCIÊNCIA}

Ainda sobre a liberdade de religiăo e de consciência, a Constituiçăo brasileira estabeleceu a possibilidade de se conciliar um possível conflito entre uma determinaçâo estatal e o cumprimento de uma conduta de cunho religioso imposta por uma determinada religiảo. Segundo o art. 5 , inciso VIII da Constituição Federal de 1988:

“VIII - ninguém será privado de direitos por motivos de crença religiosa ou de convicçăo filosófica ou política, salvo se as invocar para eximir-se de obrigaçăo legal a todos imposta e recusar-se a cumprir prestaçăo alternativa, fixada em lei. "

Percebe-se, entretanto, que há a necessidade de lei para o estabelecimento das prestaçôes alternativas, de forma que o conflito continuaria a existir se nâo houver a fixaçăo legal. (LEITE, 2014, p. 315)

Năo se pode desconsiderar, obviamente, em questôes que envolvam a escusa de consciência religiosa a ponderaçăo. No exemplo de recusa de vacinaçấo obrigatória ou mesmo transfusấo de sangue necessária, principalmente em casos que envolvam crianças, adolescente e mesmo incapazes, as soluçōes a favor da saúde e da vida, como destaca WEINGARTNER NETO (2013).

\section{ESTUDO DA RELIGIÃO PELAS CIENCIAS SOCIAIS}

Temos, porém, que considerar estudos de outras áreas ao abordarmos temas religiosos. O estudo das crenças e da religiâo de uma forma mais geral possui uma gama de aspectos abordados por diversos autores, alguns deles clássicos das Ciências Sociais.

Aqui analisaremos a religiăo sob os enfoques das tradiçôes francesa, alemă e inglesa da Antropologia através do estudo de três pensadores: Durkheim, Weber e Evans-Pritchard.

Iniciamos nosso estudo com a abordagem realizada por Durkheim sobre as práticas religiosas dos aborígenes australianos. Em As formas elementares de vida religiosa (2000), Durkheim reconhece as revelaçōes importantes feitas por etnógrafos no estudo das sociedades. O interesse de Durkheim pela etnografia surge das contribuiçóes que esta começava a prestar à Sociologia, principalmente no que diz respeito à delimitaçấo de campos de investigaçâo. A escolha pelos casos mais simples das civilizaçôes chamadas primitivas constituiu-se, na visăo de Durkheim, um procedimento revolucionário para o entendimento de certos fenômenos sociais, dentre eles os fenômenos religiosos. Para Durkheim, cada observaçâo oferece um valor de experiência, permitindo isolar verdades gerais. É o método utilizado pelo autor francês um dos pontos mais relevantes em seu trabalho sobre religiăo, uma vez que define seu objeto de estudo e busca desconstruir o que se havia dito anteriormente sobre ele. 
Durkheim busca explicar o social pelo social, tentando identificar o que há de essencial a todos os homens. Essa postura questiona o etnocentrismo, mostrando que os nativos também sâo capazes de construir um sistema religioso. A religiăo tem uma funçâo social: é a sociedade adorando-se. É a religiăo como um fato social, desmistificando-se o sagrado.

O autor francês pretende identificar o que há de essencial em cada sociedade, o que é elementar a cada religiăo. Para Durkheim, a religiăo é a "sociedade se adorando", é uma forma de enaltecê-la e que está presente a todas as sociedades, sendo o totemismo sua forma elementar. Totemismo, para esse autor, constitui-se uma crença manifestamente religiosa, implicando numa classificaçăo de seres e objetos segundo a oposiçấo entre sagrado e profano; tal oposiçăo é para Durkheim fundamental na caracterizaçấo do mundo religioso. Todos os homens participam de uma consciência coletiva e o sagrado inspira tal consciência. O totemismo relacionar-se-ia à organizaçăo da sociedade, especificamente à organizaçaáo clânica e seria o fato social mais simples, a forma elementar da religiăo e fundamental para sua análise. Nas religiôes, os homens se representariam juntamente com a sua sociedade, sendo o totemismo a forma de manifestaçăo mais simples dessas representaçôes.

Ao propor o estudo do totemismo e a partir desse fato inferir generalizaçôes acerca da natureza humana, Durkheim estava convencido de um substrato comum a todas as religióes independentemente dos estágios de desenvolvimento de umas em relaçáo a outras. Para ele, a uniformidade de uma conduta social é um indicador de uniformidade de pensamento. A semelhança entre as práticas corresponderia a uma semelhança de pensamento e de consciência entre os homens. Os fatos religiosos seriam produtos do pensamento coletivo, sendo a religiăo, portanto, explicada por fatores sociais, abordando questóes além do empiricamente observável; é o estudo do social pelo social, e nâo pelo divino, nem pelo psicológico. Mais importante que a abordagem etnográfica considerada por Durkheim é o método que ele utiliza, năo tratando sozinho do assunto, dialogando sempre com outros autores, construindo assim sua autoridade sobre o tema.

Max Weber procura compreender a forma de vida do mundo ocidental. Seu trabalho sobre religiăo em Economia e Sociedade (1996) realiza-se pelo estudo de várias questôes com o intuito de compreender essa visăo de mundo. Dessa forma, questôes econômicas, jurídicas e políticas sâo tratadas pelo autor com o objetivo de entender o mundo ocidental. $O$ estudo da religiăo náo escapa à regra e é utilizado como meio de entendimento do pensamento do ocidente. É a religiăo como açâo social.

Racionalidade é a palavra chave para Weber. Se algo segue os melhores meios para o fim, entăo é racional. O contrário seria irracional. Weber propôe que existam religiōes mais próximas da esfera racional, enquanto outras mais próximas da esfera da irracionalidade. Ao contrário de Durkheim, que procura fazer um estudo com base em etnografias para analisar a religiăo, Weber aborda grandes tradiçóes ligadas a uma análise histórica com o intuito de se entender a realidade. Análise histórica e análise etnográfica sâo fundamentais para Weber. A religiāo passa a ser um tema prático para se entender um problema de plano teórico e o totemismo um instrumento de demonstraçăo. Outra diferença para o autor francês é que Weber, além de abrir espaço para se trabalhar o indivíduo, considera o estrangeiro importante (assim como Morgan, 1973), pois tem poder transformador, ao contrário de Durkheim que năo o trata de forma 
tâo relevante e que tem como preocupaçăo fundamental as representaçóes coletivas. Enquanto para Durkheim tudo se explica pelo social, para Weber tudo se explica pela história numa eterna busca pelas origens, tentando explicar o mundo através do método compreensivo.

Weber procura descobrir as formas elementares da racionalidade, levando em consideraçăo o estudo da religiăo, mas sempre examinando assuntos da realidade, como a mudança da religiăo para a ordem jurídica. Para esse autor, as religiôes têm inspiraçâo sagrada, mas com consequências profanas, conhecimentos profanos, que fazem por exemplo a mudança da religiăo para a ordem jurídica.

Em Nuer Religion (1956), Evans-Pritchard realiza um estudo efetivamente etnográfico, convivendo com os nativos e até aprendendo sua língua como um falante fluente. O livro de Evans-Prichard é recheado de tropos, figuras de linguagem, principalmente metonímia, sinédoque, metáfora e ironia. $\mathrm{O}$ entendimento de tais figuras de linguagem mostra a interaçăo do etnógrafo com os nativos. Aliás, a dificuldade de aprender a língua é a todo instante abordada no livro, havendo uma preocupaçâo por descrever minuciosamente o que quer dizer cada termo nativo. Este trabalho de EvansPritchard é eminentemente etnográfico e a todo o momento o autor alude ao fato de ter estado no campo, para legitimar sua pesquisa e suas conclusóes. É a riqueza etnográfica um dos pontos essenciais do livro. A forma de utilizar os dados provoca conclusóes importantes como mostrar que os dados etnográficos náo envelhecem. A publicaçâo da pesquisa de Evans-Pritchard, após diversos anos da coleta dos dados, prova que a etnografia é atemporal. A análise teórica é atemporal, por isso mudanças na sociedade, posteriores ao tempo de pesquisa de campo, năo influem na análise teórica.

O autor inglês retrata a religiâo como um fenômeno filosófico. Evans-Pritchard estuda a religiăo, os fenômenos religiosos, por isso năo descreve batismos e casamentos, que náo seriam considerados fenômenos religiosos, mas sim ritos sociais. Essa é uma diferença básica para os três autores. Enquanto Evans-Pritchard estuda a religiăo propriamente dita, retirando dela tudo que náo é fenômeno religioso, Weber e Durkheim buscam estudar os vários fatores que influenciam e que săo influenciados pela religiâo. A crença religiosa para o autor inglês é fundamental, enquanto para Weber e Durkheim apenas explica o social. Outra diferença é que para Weber, quanto mais cerimônias, mais irracional é a religiâo. Evans-Pritchard, porém, discorda dessa afirmaçáo. Assim, o autor caracteriza a religiáo Nuer mostrando que ela possui pouca materialidade. Esta característica só foi possível observar devido ao processo etnográfico realizado por Evans-Pritchard. Aliás, é o processo etnográfico o fundamental no trabalho desse antropólogo inglês que legitima suas conclusóes pelo fato de estar lá e de verificar naquele caso concreto que as conclusóes de diversos estudos sobre a religiăo nâo se aplicam. Evans-Pritchard e Durkheim pretendem mostrar o mesmo, mas com enfoques diferentes. Enquanto Durkheim utiliza a religiáo primitiva para entender a sua própria religiăo, Evans-Pritchard pretende entender a religiăo Nuer, que é o ponto central do livro. Todavia, se em Durkheim é o método utilizado na abordagem das representaçōes coletivas o que se sobressai, no trabalho de Evans-Pritchard é justamente o processo etnográfico que é tido como o mais relevante.

Mais que um trabalho sobre religiăo, percebe-se que estudar a obra desses autores é buscar entender as tradiçôes do pensamento antropológico que eles representam. 
Toda a preocupaçăo da Antropologia Francesa no aprofundamento teórico de sua abordagem está presente no esforço de Durkheim ao trabalhar o totemismo e as representaçôes sociais. Da mesma forma, o trabalho de Max Weber é um fiel representante da Antropologia Alemá. Os conceitos de juízo, valor, senso comum e principalmente "Bildung" e "Verstehen" (GADAMER, 1998) tăo presentes na cultura alemă estăo presentes na obra desse autor que abre espaço para se trabalhar o indivíduo. A Antropologia Inglesa, caracterizada pelo detalhamento etnográfico, principalmente pelo fato de suas etnografias terem sido feitas em ex-colônias inglesas e por funcionários do governo, é retratada claramente na obra de Evans-Pritchard. Os estudos desses relevantes autores mostram a religiáo como um fenômeno cultural e através dela conseguimos compreender a sociedade que analisamos. A proteçâo da religiâo e da liberdade religiosa passa necessariamente pela proteçấo da identidade cultural.

\section{RELIGIÃO COMO PRODUTO DA CULTURA}

O clássico conceito de cultura do inglês E. B. Tylor afirma que cultura é "um todo complexo que inclui conhecimento, crença, arte, moral, lei, costume e quaisquer outras capacidades e hábitos adquiridos pelo homem como membro da sociedade"9 (TYLOR, 1871). Ou seja, no conceito de cultura temos a presença do sistema de crenças como fato social adquirido pelo homem como membro da sociedade. O conceito de Tylor descreve uma regularidade na religiăo e permite assim o seu estudo sistemático. (LARAIA, 1999, p. 30) O aspecto religioso ajuda a compor a identidade cultural e é um dos responsáveis pelo sentimento de pertencimento de um indivíduo a seu grupo social, a sua comunidade (COSTA, 2011).

A religiăo como um produto da cultura é um fenômeno estudado pelo antropólogo americano Clifford Geertz (1989). Tal autor procura elaborar um estudo crítico sobre a religiăo e seus aspectos culturais. Inicialmente, Geertz faz uma reflexăo sobre os estudos da religiâo e compara entre os estudos feitos antes e depois da segunda guerra mundial. Segundo ele, nâo houve um progresso teórico no estudo da religiăo, sendo acrescentados apenas dados empíricos novos. E ainda, os aspectos conceituais sâo retirados da mesma tradiçâo intelectual, năo buscando novos conceitos e informaçôes em outras áreas, como Filosofia, História, Literatura ou mesmo o Direito. Năo há dúvida que a noçăo de religiăo tem a capacidade de fazer um ajuste na conduta humana e faz uma projeçáo de uma ordem cósmica na experiência vivida pelo ser humano. A postura de Geertz é estudar a dimensâo cultural da análise religiosa e para isso ele se utiliza de um conceito de cultura que

"denota um padrâo de significados transmitido historicamente, incorporados em símbolos, um sistema de concepçóes herdadas expressas em formas simbólicas por meio das quais os homens comunicam, perpetuam e desenvolvem o seu conhecimento e suas atividades em relaçăo à vida" (GEERTZ, 1989, p. 103)

9 "Culture or Civilization, taken in its wide ethnographic sense, is that complex whole which includes knowledge, belief, art, morals, law, custom, and any other capabilities and habits acquired by as a member of society" (TYLOR, Edwar B. Primitive Culture: researches into the development of mythology, philosophy, religion, art, and custom. London: John Murray, 1871, p. 1). 
A religiâo assume uma importância ao ter a capacidade de permitir a efetivaçăo de funçōes sociais, psicológicas e culturais a partir do momento em que é capaz de servir o indivíduo e o grupo como modelo para suas atitudes. Com a religiăo, há um aperfeiçoamento tanto das relaçóes sociais quanto de acontecimentos psicológicos. Mas da mesma forma que as crenças religiosas săo reflexos de processos sociais, a religiâo consegue influenciar e modelar os aspectos sociais ${ }^{10}$.

Segundo Geertz, religiăo seria:

\begin{abstract}
“Um sistema de símbolos que atua para estabelecer poderosas, penetrantes e duradouras disposiçóes e motivaçóes nos homens através da formulaçăo de conceitos de uma ordem de existência geral e vestindo essas concepçōes com tal aura de fatalidade que as disposiçóes e motivaçôes parecem singularmente realistas" (GEERTZ, 1989, p. 104-105)
\end{abstract}

No estudo da religiăo, Geertz afirma que temos dois estágios: um seria uma análise de sistemas de significados que foram incorporados pelos símbolos da religiâo, e um outro que seria a relaçấo de tais símbolos com os processos sociais e psicológicos. 0 estudo da religiăo, antes de ser um estudo sobre seus rituais, é uma análise sobre a condiçăo humana, sobre a noçăo dos homens nos seus aspectos racional, prático, humano e também quanto ao aspecto moral.

A religiăo aborda o ser humano em diversos aspectos. Essa multiplicidade gera algumas dificuldades. $\mathrm{O}$ conceito jurídico de religiăo, por exemplo, enfrenta um problema no que diz respeito a legitimidade, ou seja, saber a quem cabe definir um conceito jurídico de religiăo, uma vez que o conceito năo é exclusivamente jurídico. Qual o órgăo mais apto a definir a religiăo: um juiz, um tribunal ou o legislador? O Direito percebe essa dificuldade, que é tratar de um tema que envolve outras áreas do saber, como as ciências sociais e psicologia, além de aspectos históricos. WEINGARTNER NETO (2007) mostra a dificuldade de se estudar o campo religioso na cultura "...as culturas sâo mais que simples racionalidade, agregando-se duas outras dimensóes à realidade (sobremodo importantes no campo religioso e mais refratárias à explicitaçáo conceitual), a mítico-simbólica e a do mistério". (WEINGARTNER NETO, 2007, p. 97)

Para Jónatas Machado, citado por WEINGARTNER NETO (2007), há três tipos de vertentes conceituais: a) substancial-objetiva: tem uma prevalência na decisăo da Suprema Corte Americana, nos conhecidos Mormon cases, do final do século XIX, que define a religiâo com base em critérios substantivos a partir da presença dos elementos divindade, moralidade e culto no conteúdo religioso da crença abordada; b) funcional-subjetiva: esse conceito é baseado numa tendência americana presente a partir dos anos 60, principalmente diante do problema da objeçâo de consciência e em específico a recusa ao serviço militar durante a guerra do Vietnă por questăo de crença religiosa. Nesse conceito, importa o elemento subjetivo da sinceridade, ou seja, sem adentrar especificamente no conteúdo da crença, busca-se saber se é uma forma consciente de crença, se há convicçâo do indivíduo em acreditar naquela religiâo; c) tipológico: esse conceito busca ser amplo e expansivo para nâo restringir a liberdade

10 OSupremo Tribunal Federal decidiu no julgamento da Açáo Direita de Inconstitucionalidade (ADI) 4439, em 27 de setembro de 2017, que o ensino religioso nas escolas públicas brasileiras pode ser de natureza confessional. 
religiosa e ao mesmo tempo ser operacional para evitar uma utilizaçăo abusiva. Jonatas Machado ressalta que a religiăo, segundo o conceito tipológico, deve propor uma visáo geral do mundo, um apelo a autoridade de valor extra-racional, além da consciência de um poder sobrenatural e ainda de uma ideia de heteronomia, em que o indivíduo entende o elemento religioso năo como algo endógeno a sua consciência, mas sim com uma imposiçăo de natureza exógena.

\section{PROTEÇÃO LEGAL DA RELIGIÃO COMO DIREITO CULTURAL}

A identidade cultural de um grupo é estabelecida, entre outros diacríticos identitários, pelo pertencimento dos indivíduos àquele território e àquela comunidade por seguirem o seu sistema de crenças (COSTA, 2011). Dessa forma, por todos os motivos elencados anteriormente, a proteçăo ao sistema de crenças e a religiâo deve decorrer também das normas de proteçăo a cultura, uma vez que a caracterizaçâo de um grupo culturalmente considera o respeito que cada membro daquele grupo tem pelo sistema de crenças respeitado na comunidade.

Se cultura é "algo alheio, mas que permite o reconhecimento do outro, e nos conduz a pensar que nós pertencemos a uma cultura, uma forma de viver, um modelo que é um entre os muitos possíveis", como afirma Carlos Alberto Molinaro (2013), a identidade cultural considera o sistema de crenças. Se a religiăo também é fruto da cultura ${ }^{11}$, a sua proteçăo tem que ser feita nos mesmos moldes da proteçâo aos direitos culturais. ${ }^{12}$

A Constituiçăo Federal de 1988, em seus artigos 215 e 216, II, protege a cultura ao afirmar ${ }^{13}$ :

11 Para Richard Caddell e Shea Esterling, o avanço dos direitos culturais ampliou a compreensâo sobre os demais direitos, dentre eles o da liberdade de religiâo: "In this way, the concepts of freedom of religion, education and expression, alongside the principle against discrimination, have been deepened and enriched with reference to the cultural rights imperative" (CADDELL; ESTERLING, 2011, p. 9)

12 O Conselheiro Oscar Argollo, relator para o acórdáo do pedido de providências no 1345, do CNJ, data de julgamento 06.06.2007, ao julgar o pedido de retirada de crucifixos de salas do Poder Judiciário, afirma que a cultura e a tradiçâo proporcionam aos cidadāos uma exposiçâo de símbolos que representam a nossa cultura e com os quais convivemos pacificamente, como é o caso do crucifixo e da estátua. Nas palavras do Conselheiro,

"Entendo, com todas as vênias, que manter um crucifixo numa sala de audiências públicas de Tribunal de Justiça náo torna o Estado laico - ou o Poder Judiciário - clerical, nem viola o preceito constitucional invocado (CF. art. 19, I), porque a exposiçâo de tal símbolo nâo ofende o interesse público primário (a sociedade), ao contrário, preserva-o, garantindo interesses individuais culturalmente solidificados e amparados a ordem constitucional, como é o caso deste costume, que representa as tradiçôes de nossa sociedade." Disponível em: http://www.cnj.jus.br/InfojurisI2/Jurisprudencia. am?jurisprudenciaIdJuris=45630 \&indiceListaJurisprudencia=1 \&tipoPesquisa=LUCENE\&firstResult=0

13 Para Carlos Alberto Molinaro, os direitos culturais sāo direitos fundamentais:

"A cultura e os direitos culturais sâo na sistemática constitucional brasileira, direitos fundamentais, individuais e sociais, neste sentido gozam da perenidade que lhes empresta à cláusula de vedaçáo contida no inciso III do art. 60 da CF. A expressăo cultura utilizada pelo constituinte de 1988 tem endereço certo, dirigindo imediatamente a significaçāo das capacidades do fazer humano e todas as suas manifestaçôes, espirituais, artísticas, intelectuais, científicas bem como a formataçáo de uma subconstituiçăo cultural, que pode inclusive caracterizar um Estado de Cultura, onde a expressáo máxima está vinculada ao acervo comum da identidade de cada um dos grupos que coopera para a identidade nacional, desde suas memórias históricas, condiçōes étnicas, produçâo artística, intelectual, filosófica e sociológica." (MOLINARO, 2013, p. 1982) 
Art. 215. O Estado garantirá a todos o pleno exercício dos direitos culturais e acesso às fontes da cultura nacional, e apoiará e incentivará a valorizaçăo e a difusăo das manifestaçōes culturais.

Art. 216. Constituem patrimônio cultural brasileiro os bens de natureza material e imaterial, tomados individualmente ou em conjunto, portadores de referência à identidade, à açăo, à memória dos diferentes grupos formadores da sociedade brasileira, nas quais se incluem:

II - os modos de criar, fazer e viver.

No plano internacional, contamos amplamente com a proteçâo da cultura pelos tratados ${ }^{14}$. Săo exemplos a Convençăo dos Direitos Econômicos, Sociais e Culturais, que afirma no seu artigo $1^{\circ}$ :

\section{Artigo $1^{\circ}$}

$\S 1$. Todos os povos têm o direito à autodeterminaçăo. Em virtude desse direito, determinam livremente seu estatuto político e asseguram livremente seu desenvolvimento econômico, social e cultural

Jáem1970,comaConferência Intergovernamentalsobre os Aspectos Institucionais, Administrativos e Financeiros das Políticas Públicas, que foi celebrada em Veneza, já se percebia uma preocupaçăo dos países com o desenvolvimento de políticas públicas para a cultura.

A Carta da ONU, de 1948, também protege a cultura, nos seguintes artigos:

Artigo 22:

Todo o homem, como membro da sociedade, tem direito à segurança social e à realizaçáo, pelo esforço nacional, pela cooperaçáo internacional e de acordo com a organizaçăo e recursos de cada Estado, dos direitos econômicos, sociais e culturais indispensáveis à sua dignidade e ao livre desenvolvimento de sua personalidade.

Artigo 27:

I) Todo o homem tem o direito de participar livremente da vida cultural da comunidade, de fruir as artes e de participar do progresso científico e de fruir de seus benefícios.

II) Todo o homem tem direito à proteçáo dos interesses morais e materiais decorrentes de qualquer produçáo científica, literária ou artística da qual seja autor.

Esses instrumentos legais utilizados na proteçăo da diversidade cultural (COSTA, 2017) também săo adequados para a proteçăo da religiăo, enquanto aspecto da cultura humana ${ }^{15}$.

14 SAWSON (2017) promove um debate entre a aplicaçáo dos direitos econômicos, sociais e culturais nos Estados Unidos, Brasil, Índia e Myanmar.Cf.SWANSON, Reedy C. Decentering or Decentralizing:Economic, Social, \& Cultural Rights in Federal Systems, 57 Virginia Journal of International Law. 129, 2017.

15 Sharon O'Brien (1987), ao estudar o reconhecimento e a proteçăo dos direitos culturais nos Estados Unidos, evidecia que uma das medidas para se proteger a cultura indígena naquele país foi o compromisso 


\section{CONSIDERAÇÕES FINAIS}

A separaçâo entre Estado e religiăo foi um momento importante na história moderna que teve como consequência a soberania popular como fonte do poder político. Essa separaçăo também ocasionou algumas transformaçóes imediatas como a liberdade da ciência, a tolerância ao pluralismo religioso e a inviolabilidade dos direitos humanos e fundamentais. Conquistas que existem até os dias atuais.

Se por um lado temos a separaçăo entre Estado e religiăo, nâo impondo uma religiấo oficial aos cidadâos, as diversas religiôes devem ser protegidas, inclusive aquelas consideradas minoritárias. A liberdade religiosa, como um dos primeiros direitos fundamentais, protege a religiâo na medida em que resguarda a consciência e a crença dos cidadáos. A Constituiçâo Federal possui incisos significativos no artigo $5^{\circ}$ protegendo essa liberdade. Por outro lado, temos que considerar que a religiăo é um produto da cultura. Os estudos analisados neste trabalho mostram os aspectos culturais presentes nas questōes religiosas. Como um Estado laico năo significa um Estado ateu, tais aspectos religiosos, no nosso entender, devem ser protegidos a partir dos mecanismos que resguardam também os direitos culturais. Dessa forma, no Estado Democrático de Direito, a religiâo deve conviver com igualdade, dignidade da pessoa humana, justiça social e pluralismo intercultural.

federal de proteger a religiâo indígena por meio da legislaçăo e de regulamentos, reconhecendo, segundo o "Indian Religious Freedom Act, de 1978", por exemplo, que as práticas religiosas dos indígenas americanos fazem parte de sua cultura e tradiçáo e săo indispensáveis e insubstituíveis. (O'BRIEN, Sharon. Cultural Rights in the United States: A Conflict of Values, 5 Law and Inequality. 267, 1987, p. 298-299). 


\section{REFERÊNCIAS}

BRASIL. Constituiçâo Federal (1988). Constituiçâo da República Federativa do Brasil: promulgada em 5 de outubro de 1988. Sáo Paulo: Atlas, 2018.

CADDELL, Richard; ESTERLING, Shea. The Cultural Rights Imperative, 42 Cambrian L. Rev. 7, 2011.

COSTA, Sebastiăo P. Mendes da. Conhecimentos tradicionais: direito à proteçâo e proteçâo aos direitos. Teses de doutorado. Programa de Pós-Graduaçăo em Direito. PUCRS, Porto Alegre-RS, 2017.

COSTA, Sebastiăo P. Mendes da. Pertencimento, memória coletiva e territorialidade em uma comunidade rural do Piauí. Dissertaçâo de Mestrado. Programa de Pós-Graduaçâo em Antropologia e Arqueologia. Universidade Federal do Piauí, Teresina-PI, 2011.

DURKHEIM, Emile. As formas elementares da vida religiosa. Săo Paulo: Martins Fonte, 2000.

EVANS-PRITCHARD, E. E. Nuer Religion. London: Oxford Press, 1956.

FARIA, Edilsom. Estado e religiăo: uma separaçăo de interesse público. Diplomatique. 09 de set. 2009. Retirado do site: http://www.diplomatique.org.br/artigo.php?id=545

GADAMER, Hans-Georg. Verdade e Método. Petrópolis: Vozes, 1998.

GEERTZ, Clifford. A interpretaçâo das culturas. Rio de Janeiro: LTC, 1989.

GORNIG, Gilbert; TRUE, Christiane. Minority Protections in Germany. 6 Tilburg Foreign Law Review 69, 1997.

LARAIA, Roque. Cultura: um conceito antropológico. 12. ed. Rio de Janeiro: Zahar, 1999.

LEITE, Fábio Carvalho. Estado e religiāo: A liberdade religiosa no Brasil. Curitiba: Juruá, 2014.

MELLO FILHO, José Celso. Constituiçāo Federal Anotada. 2. ed. Săo Paulo: Saraiva, 1986. p. 440.

MOLINARO, Carlos Alberto. Comentário ao arts. 215 e 216. In: CANOTILHO, J. J. Gomes; MENDES, Gilmar; SARLET, Ingo; STRECK, Lenio. (Coords.) Comentários a Constituiçâo do Brasil. Sâo Paulo: Saraiva/Almedina, 2013. p. 1976-1985. 
MORGAN, Lewis H. A sociedade primitiva. Lisboa: Presença, 1973.

O'BRIEN, Sharon. Cultural Rights in the United States: A Conflict of Values, 5 Law and Inequality. 267, 1987.

ROBBERS, Gerhard. Religious Freedom in Germany. Brigham Young University Law Review 643, 2001.

SARLET, Ingo Wolfgang. A eficácia dos direitos fundamentais: uma teoria geral dos direitos fundamentais na perspectiva constitucional. 12. ed. rev. atual. Porto Alegre: Livraria do Advogado, 2015.

SWANSON, Reedy C. Decentering or Decentralizing: Economic, Social, \& Cultural Rights in Federal Systems, 57 Virginia Journal of International Law. 129, 2017.

THE EUROPEAN COURT OF HUMAN RIGHTS. Case S.A.S vs France. Strasbourg, 01.07.2014 Decisăo disponível em: https://hudoc.echr.coe.int/eng\#\{\%22appno\%22:[\%2243835/11\%22],\%22itemid\%22:[\%22001-145466\%22]\} Acesso em: 28.06.2018

TYLOR, Edwar B. Primitive Culture: researches into the development of mythology, philosophy, religion, art, and custom. London: John Murray, 1871

WEBER, Max. Economia e Sociedade. vol. 1. Brasília: EdUnB, 1996.

WEINGARTNER NETO, Jayme. Comentário a o art. 5º VI a VIII. In: CANOTILHO, J. J. Gomes; MENDES, Gilmar; SARLET, Ingo; STRECK, Lenio. (Coords.) Comentários a Constituiçâo do Brasil. Sáo Paulo: Saraiva/Almedina, 2013. p. 264-273.

WEINGARTNER NETO, Jayme. Liberdade religiosa na Constituiçâo: fundamentalismo, pluralismo, crenças, cultos. Porto Alegre: Livraria do Advogado: 2007. 